\title{
Italian Jihadists in Syria and Iraq
}

\section{by Francesco Marone}

\section{(cc) BY}

This work is licensed under a Creative Commons Attribution 3.0 License.

\section{Abstract}

This article explores the current extent of Italy's Sunni jihadists in Syria and Iraq. The country presents interesting particularities, including a relatively small number of foreign fighters compared to other European countries (not more than 90 individuals, and only a dozen with Italian passports). However, the Italian case has not been extensively investigated. This article first examines the scale of the problem and then focuses on the cases of three Italian nationals who left for Syria: a convert who died in combat in the Aleppo area in 2013, a second-generation immigrant who joined the ranks of the Islamic State (IS) and a muhajira ("emigrant") who, as a woman, has not been allowed to take combat roles in the self-proclaimed "caliphate".

Keywords: Terrorism; radicalisation; jihadism; foreign fighters; muhajirin; Islamic State; Italy

\section{Introduction}

Over the last few years the authorities in a number of countries have expressed strong concerns about the thousands of citizens and residents joining the ranks of jihadist armed groups in Syria and Iraq.

As is well-known, the danger of so-called "foreign fighters" is high on the agenda. These individuals can access militant groups, acquire weapons training and combat experience and develop radical anti-Western positions (among others, Byman and Shapiro, 2014). Clearly, in addition to their debatable role in conflict areas (Bakke, 2014; Rich and Conduit, 2015), the fear is that some of them return to their home countries or to a third country and carry out or support terrorist attacks.[1]

This threat is serious in Europe. According to an estimate by the International Centre for the Study of Radicalisation and Political Violence (ICSR), the number of foreign fighters from Western European countries rose to nearly 4,000 (Neumann 2015). In April 2015, the EU Justice Commissioner, Věra Jourová, said in an interview that "at the European level, we estimate that 5,000 to 6,000 individuals have left for Syria", adding the true number was likely to be far higher because of the difficulty of tracking foreign fighters in the conflict (Gonzales, 2015).

Against this background, the contingent of Italy's jihadists who travelled to Syria and Iraq appears to be fairly small. According to the latest estimates (September 2015), the number of foreign fighters from Italy - Italian citizens or not - is probably not more than 90 individuals. After all, this is a modest figure, compared to recent estimates (Neumann, 2015) for other large European countries, such as France (1,200 fighters), the UK (500-600) (Pantucci, 2014) and Germany (500-600) (Heinke and Raudszus, 2015); and low even compared to less populous countries such as Belgium (440) and Denmark (100-150).

This article explores the current extent of Italy's Sunni jihadists in Syria and Iraq. Unlike other Western countries, the Italian case has not been extensively investigated.[2] This paper aims to help fill a gap in the 
scientific literature. The analysis draws on both primary sources (in particular, original jihadist materials) and secondary sources (scientific works, journalistic pieces, official reports).

The text is organised in four sections. The first section examines the scale of the problem. The second analyses the backgrounds, motivations and activities of three Italian jihadists on whom open-source information is available: two male foreign fighters and a female muhajira ("emigrant"). It should be said that, regardless of their motivations, women who have joined jihadist armed groups in Syria and Iraq cannot be considered as genuine foreign fighters because at the moment such groups do not allow them to take combat roles. The third section discusses these three individual cases, underlining points of similarity and difference. The conclusions recapitulate the most important findings presented in the article.

\section{The Italian contingent}

The Paris attacks of January 7-9, 2015 provided an opportunity to take stock of the situation in Italy. On January 18, 2015, during a press conference, Interior Minister Angelino Alfano presented official data on foreign fighters connected with the country. According to the Minister, 59 foreign fighters had connections with Italy (Italian Interior Ministry, 2015). Not all of them were on the national territory at the time. In fact, in his words, there were "five Italians who left for Syria, two individuals with dual nationality, 15 foreigners who left from Italy, 25 foreigners linked to the country in various forms and 13 Syrians who left from Italy". In addition, 14 foreign fighters had already died in combat (Italian Interior Ministry, 2015; Marone, 2015, p. 300). The Interior Minister did not add other information, including names and ethnicities, on grounds of secrecy.

In September 2015, Defence Minister Roberta Pinotti said that 87 foreign fighters travelled from Italy. Only 12 individuals had Italian passports; in her words, "six were Italian nationals and another six had dual nationality" (Il Sole 24 Ore, 2015).

Some of these foreign fighters are connected with the local home-grown jihadist milieu, made up of converts and second-generation immigrants (with or without Italian passports) (Vidino, 2014). This home-grown jihadist scene has only recently emerged in the country, arguably not before 2009, and it is still relatively small in size, especially in comparison with other Western European countries.

As for second-generation immigrants, the limited scope of this threat is, to some extent, the result of a simple demographic factor: large-scale Muslim immigration to Italy began only in the late 1980s and early 1990s and therefore the first wave of second-generation Muslims has only recently entered adulthood (Vidino, 2014, p. 8).

Today very few Italian nationals are publicly known to have joined armed groups in Syria or Iraq. However, these individuals deserve attention because they are particularly difficult to detect and stop. In fact, fullfledged Italian citizens may appear to be above suspicion. Furthermore, they cannot be expelled. By contrast, many home-grown jihadists who were born or grew up in the country may not have citizenship, because of Italy's strict naturalization laws, and could therefore be subject to deportation (Vidino, 2014, pp. 9, 77, 104).

\section{Three individual cases}

Although, in general, there is little public information on Italy's foreign fighters and other jihadists who left for Syria and Iraq, three cases are relatively well-known. They concern: Giuliano Delnevo, a convert who died in combat in the Aleppo area in 2013; Anas el Abboubi, a second-generation "born-again" Muslim who 
joined the ranks of the Islamic State (IS) in 2013; and Maria Giulia Sergio, a female convert who is now in the self-proclaimed "caliphate", where she has received some weapons training. Delnevo and el Abboubi served as foreign fighters alongside an al-Qaeda-linked group and IS, respectively, while Sergio, as a woman, is not allowed to engage in combat. All three have Italian passports.

This section reconstructs their backgrounds, motivations, and activities, on the basis of currently available information. While this is a small sample, it is drawn from a relatively small population and can contribute to a better understanding of the foreign fighter threat in Italy.

\section{Giuliano Delnevo}

Giuliano Delnevo was born in 1989 in the north-western city port of Genoa to a Catholic middle-class family. His parents separated when he was a child. He grew up in the historic centre of the city, one of Italy's most ethnically diverse areas (Pieracci, 2013; Vidino, 2014, pp. 69-74).

He was a quite introverted person and experienced socialisation and academic difficulties in his teenage years. The closest among his few friends was an undisciplined classmate of Moroccan descent, Naim. Once turned 18, Delnevo and his friend spent some months in Ancona, in central Italy, where Giuliano's older brother worked as a nautical engineer (Piccardo, 2013; Delnevo, 2015). There Delnevo got a job as a handyman in a shipyard and met a group of fellow workers, probably from Bangladesh, who reportedly were members of Tablighi Jamaat, the Islamic missionary movement established in India in the 1920s. In 2008, Delnevo converted to Islam and took the name Ibrahim (Delnevo, 2014; Vidino, 2014, pp. 69-70).

Once back in Genoa, Delnevo enrolled in university but preferred to devote most of his time to Islam. He befriended Umar Andrea Lazzaro, another Genoese convert who was known for his previous militancy in the local far-right scene and his strong anti-American sentiments (Grasso and Indicre, 2014).[3] Lazzaro and Delnevo were the driving force of a small group of converts operating in the city of Genoa, inspired mainly by the Deobandi school, the Indo-Pakistan revivalist movement established in 1867. According to the information available, most local mosques shunned these converts. Thus, the small group started to seek contact with more established Islamist circles in other European countries. Following a trip to the UK, Delnevo was investigated in Genoa on suspicion of enlistment for the purposes of international terrorism (Imarisio, 2013). According to unconfirmed reports, he also visited Chechnya (Pieracci, 2013).

Delnevo was active on the Internet. He created a Facebook profile and a YouTube channel which he called LiguristanTV (Liguria being the Italian region of which Genoa is capital).[4] In his online production, the Genoese convert created an original hybrid, mixing the usual narrative of jihadism with Western and Italian themes, such as leftist anti-imperialist symbols, images of youth rebellion, and even celebratory references to the Italian nation (Vergani, 2014).

Delnevo did not study or work and all his life resolved around Islamic activism. He became increasingly militant. Online he met a Moroccan woman 13 years his senior and married her soon after. He moved to Tangier, but returned without her after a few months (Vidino, 2014, p. 72). She remained in Morocco with her family. In Genoa Delnevo separated from his small group of converts and broke with his friend Lazzaro, a 


\section{Journal of Terrorism Research}

reflective person seemingly more interested in his studies than in action (Imarisio, 2013; Grasso and Indicre, 2014).

Delnevo began looking for connections that would allow him to join a field of jihad abroad. In the summer of 2012, he travelled to Turkey and from there sought to cross into Syria but his attempt failed and he returned to Italy.

He tried again a few months later, with more success. First, he shaved his long beard and started wearing Western clothes again. Then, on November 27, 2012, he went to Turkey by plane and reached Syria. After a few weeks, he called his father, telling him he had travelled to Syria and joined a group of foreign fighters led by Chechen militants; that is the Katibat al-Muhajirin (Brigade of the Emigrants).[5] He appeared to be enthusiastic about his experience and optimistic about the final outcome of the conflict against the Assad regime (Vidino, 2014, pp. 73-74).

In a dramatic Skype conversation on June 11, 2013, Delnevo told his father that the enemy was only 100 meters away and to pray for him. On the next day his father received a call from a man named Zamza, possibly a Chechen commander, using Delnevo's cell phone, telling him that his son Giuliano / Ibrahim had died the night before while trying to help a fellow fighter of Somali origin who had been shot (Delnevo, 2014, 2015; Persano, 2013). The Genoese foreign fighter lost his life near the village of Kafr Hamrah, in the north-west of Syria (Delnevo, 2015). He was the first Italian foreign fighter to fall in battle. His eulogy, which referred to him as Abu Musa, was featured on various jihadist websites (Vidino, 2014, p. 74).

From December 2012 to March 2013, Delnevo's mother, Eva Guerriero, travelled along the border between Turkey and Syria in her search of her son, but she did not succeed in finding him (Calandri, 2013). In a visit to Syria in the autumn of 2013, after his death, she managed to find Giuliano / Ibrahim's diary (Preve, 2014). [6] This document was consigned to the public prosecutor's office of Genoa and, at the time of writing, apart from few passages, its content has not been made available (Dellacasa, 2014). Delnevo's body has not been found and officially he is still under investigation for recruitment with the aim of international terrorism (Grasso, 2014).

Delnevo's father, Carlo, has repeatedly described his son as a "hero" (Persano, 2013), even though he explicitly does not share his radical ideas (La Repubblica, 2014). His statements caused controversy in the country (e.g., Ansa, 2015). In early 2014, Carlo Delnevo, a "practicing Catholic" in his own words, decided, accepting his son's wishes, to convert to Islam (Delnevo, 2015).

\section{Anas el Abboubi}

Anas el Abboubi was born in Marrakech, Morocco, in 1992, but moved to Italy when he was seven. He lived with his well-integrated Muslim family in Vobarno, a small rural town near Brescia, in northern Italy (in particular, Vidino, 2014, p. 60).

In high school, el Abboubi developed a passion for rap and was active in the Brescia hip hop scene under the name of McKhalifh. In March 2012, he appeared in a MTV reportage on Muslim young musicians in Italy. In this mini-documentary, he expressed ambivalent, albeit not hostile, feelings toward Italians and described with satisfaction his "return" to Islam a year and a half before the interview.[7]

Nevertheless, in a few months, el Abboubi went from being a restless teenager using alcohol and light drugs to a rapper motivated by Islam and, finally, a committed jihadist militant (Vidino, 2014, p. 62). Tellingly, he changed the content of the YouTube channel he had held since his rap days to bring it more in line with 


\section{Journal of Terrorism Research}

his new religious zeal.[8] In the summer of 2012, he began to follow and produce Islamist material on the Internet, under the name of Anas Abu Shakur. In particular, he lashed out at the values and institutions of Western civilisation (including individualism and sexual promiscuity, man-made legal systems, global capitalism and the banking system[9]) and denounced the "crusade against Islam of the new world order" led by the US. He also displayed anti-Jewish sentiments. Furthermore, he openly expressed his desire to travel for jihad (Vidino, 2014, pp. 63-64).

El Abboubi soon got in touch with other jihadist activists, especially in central and northern Europe (the UK, Belgium, Germany). He was also in contact with Giuliano / Ibrahim Delnevo. Moreover, he tried to open the Italian branch of the radical Sharia4 franchise,[10] Sharia4Italy,[11] although without much success (Micalessin, 2014).

Italian authorities have monitored his activities at least since September 2012. On June 12, 2013, they decided to arrest el Abboubi after becoming concerned by the increased militancy of his online activities and, above all, by the fact that he had used the internet to research various iconic sites in Brescia (Italian State Police, 2013; Petenzi, 2013). The worry was that he could be planning attacks in the city. However, on June 28, 2013, he was released, as the court did not deem his behaviour a violation of the law (Rodella, 2013a).

On September 14, 2013 Abboubi travelled to Syria, via Turkey (Rodella, 2013b; Rodella, 2015a), where he became a fighter of the Islamic State of Iraq and al-Sham (now Islamic State). In order to arrange his travel, el Abboubi contacted a small group of Albanian jihadist facilitators who operated between the Balkans and Italy (Petenzi, 2015). Two Albanian citizens, uncle and nephew, were arrested on these grounds by Italian authorities in March 2015 (Rodella, 2015b).[12]

In August 2013, el Abboubi created a new Facebook profile, quite active, under the name Anas al-Italy and indicated his job as "jihad". However, since January 2014 this profile has no longer been available (Rodella, 2014). The last phone call with his mother was on January 28, 2014 (Rodella, 2015a).

The fate of Anas is uncertain. At the time of writing, it is not clear whether he is still alive (Rodella, 2015c).

\section{Maria Giulia Sergio}

Maria Giulia Sergio, a 28-year-old woman, was born in Torre del Greco, near Naples, to a Catholic family (father, mother and an older sister). The family had economic problems and decided to move to northern Italy around 2000; they settled in Inzago, a town between Milan and Bergamo. There her sister Marianna (born in 1985) married a Muslim immigrant of Algerian origin.

After high-school, Sergio studied biotechnology at the State University of Milan. She also worked in parttime jobs to pay for her studies. In September 2007, she converted to Islam on her own initiative and took a new name, Fatima az Zahra.[13] In her words, the Internet facilitated a sudden conversion experience (Assumma, 2013; Sarfatti, 2015). Initially her parents did not approve of her decision (Serafini, 2015b, p. 39).

After two years, Maria Giulia / Fatima married Jamal, a local pizza maker of Moroccan origin, but in 2011 filed for divorce, possibly disappointed by his lack of religious fervour.

On October 5, 2009, she participated in a popular TV show (Pomeriggio 5) where she argued for the use of the headscarf (hijab) for Muslim women and supported the idea of a "pluralist system" in society (Biloslavo, 2015b). Around that time, she adopted the niqab (the veil that covers the entire face with only a slit for the eyes). In addition, on September 16, 2011, she subscribed to a petition in favour of the niqab, along with her 


\section{Journal of Terrorism Research}

sister and her mother. The petition was signed by Delnevo and Lazzaro, too, and was reportedly written by the latter (Biloslavo, 2015a).[14]

Sergio felt she was a victim of religious discrimination (Serafini, 2015b, pp. 42, 46-47). Furthermore, over time, her positions became increasingly radical. On September 17, 2014, in the mosque of Treviglio, near Bergamo, she married an Albanian citizen, Aldo "Said” Kobuzi,[15] in an apparent marriage of convenience, facilitated by a mutual acquaintance of Albanian origin, Lubjana Gjecaj. Sergio soon moved to Kobuzi's house near Grosseto, in Tuscany. Just four days after the marriage, Sergio and her new husband took an airplane from Rome to Istanbul and then reached Syria from Gaziantep, where they joined the so-called Islamic State (IS). They settled near the Tishrin Dam on the Euphrates, in the Aleppo Governorate, where they were probably reunited with Kobuzi's sister and mother (Serafini, 2015b, pp. 86-87, 97).

In her eyes, Sergio fulfilled the duty of the "journey" (Hijra)[16] to the newly-claimed "caliphate", responding to Abu Bakr al-Baghdadi's call; in this way, she became a muhajira (female "emigrant", from the same root of Hijra) (Perešin, 2015; Perešin and Cervone, 2015). In Syria, Sergio took up firearms training, waiting to take part in combat someday (Serafini, 2015b, pp. 102, 132-133). She explicitly expressed her desire to fight. [17] Thus, strictly speaking, Maria Giulia / Fatima is not a foreign fighter, but only because at the moment IS, basing its activity on a rigid interpretation of Sharia law, prefers not to use women in military combat (cf. Cook, 2005; Lahoud, 2014). However, this does not preclude the possibility that she could conduct acts of violence in the self-proclaimed "caliphate" or in other countries (cf. Perešin, 2015, pp. 31-32). For his part, Aldo Kobuzi went to an IS training camp in Iraq in November 2014 (Serafini, 2015b, pp. 96-98).

One by one, all family members of Sergio converted to a very strict form of Islam. On July 1, 2015, Italian police arrested Sergio's father, mother and sister[18] in their house in Inzago, on charges of travel for the purposes of international terrorism and criminal association:[19] they were preparing to go to Syria and join the self-proclaimed "caliphate", convinced by the young woman's pressing requests (Berizzi, 2015). On the same day, two Albanian relatives of Aldo Kobuzi (his uncle Baki Coku and his aunt Arta, alias Anila, Kacabuni) were arrested. Five arrest warrants were also issued for the Kobuzi-Sergio couple, two other Kobuzi-Coku relatives (his sister Serjola and his mother Donika Coku) and an Italian-born woman with Canadian passport, Bushra Haik. [20] At the time of writing, they are still wanted (Italian State Police, 2015).

Italian authorities had intercepted Sergio's Internet and SMS communications with her relatives in Italy. These wiretaps give a valuable insight into Sergio's activities and motivations. Among other things, in these conversations (actually, almost monologues), this assertive woman endorsed the duty to "destroy the unbelievers" and expressed a strong desire to "die as a martyr". Moreover, she referred, generically, to the presence of "mujahidin in Italy who have connections". She also prefigured the progressive expansion of the self-proclaimed "caliphate" to Rome itself: in her words, "towards the end, Insha'Allah, we will go to Rome, too, as the Prophet said (...) In Rome there will be a great battle" (Sergio, 2015; Serafini, 2015b, p. 137).

According to Italian investigators, these wiretaps led to the Turkish phone number of an "important IS member", Ahmed Abu al-Harith, who coordinated the arrival in Syria of foreign fighters from different countries (Santucci, 2015; Serafini, 2015b, pp. 76-82).

Sergio has peculiarly contrasting views about the role of women. On one hand, she appears to be a strongminded woman and certainly represents the driving force in her family; but, on the other hand, she maintains that women should recognise the superiority of men. Tellingly, in an intercepted Skype conversation, Maria Giulia / Fatima paradoxically demanded that her father impose his (actually, her) will on her mother, by saying: "you are in charge (...) you decide, you are the man of the house and then grab mum by her hair and 


\section{Journal of Terrorism Research}

come here [to Syria] and make Hijra! She doesn't need to have any opinion about it" (Sergio, 2015; Serafini, 2015b, p. 131).

On July 5, 2015, Sergio gave a striking interview to Italy's most important newspaper (Serafini, 2015a; Serafini, 2015b, pp. 9-15). In a short Skype conversation, Maria Giulia / Fatima denounced her relatives' arrests as "illogical and irrational". Furthermore, she glorified IS as a "perfect state" based on Sharia law. She denied the accusation of human rights violations in the newly-proclaimed "caliphate" but at the same time defended the use of beheadings and other forms of corporal punishment. The entire interview was conducted by her in a self-confident, doctrinaire tone.

\section{Radicalisation pathways}

These three stories present similarities but also important differences. With regard to socio-demographic characteristics, all protagonists were quite young: Delnevo was born in 1989, el Abboubi in 1992, Sergio in 1987. They all lived in northern Italy (in the regions of Lombardia and Liguria), in the richest and most dynamic part of the country. None suffered conditions of poverty or social exclusion, although Sergio's family of origin had experienced some economic difficulties.

As for psychological factors, none showed signs of mental illness. On the other hand, they differed markedly in their personality traits: in particular, while Delnevo was a troubled young man (Delnevo, 2015; Grasso, 2014), Sergio is a strong-minded, self-confident person (Serafini, 2015b, pp. 9-15ff.).

Apart from a few similarities, there are no indications of a specific profile. This conclusion is in line with the findings of the current literature on radicalisation. In fact earlier attempts to draw conclusions from sociodemographic variables and to identify the "terrorist personality" have been largely abandoned. Rather, today there is a general tendency to "shift the focus away from profiling extremists to profiling the radicalization pathways they take" (Hafez and Mullins, 2015, pp. 959)

As most Italian homegrown jihadists (Vidino, 2014), their radicalisation pathways did not take place in traditional settings, such as radical mosques or prisons. On one hand, el Abboubi had no strong connections with Islamic places of worship or cultural centres (Valle Sabbia News, 2013; Vidino, 2014, p. 79); Delnevo went to mosque from time to time and, for a short time, frequented a mosque with "known militant ties" near Imperia (Vidino, 2014, p. 73), not far from Genoa; while Sergio attended a few mosques quite regularly. However, on closer inspection, mosque attendance did not play a crucial role in their decision to join jihadist groups in Syria. On the other hand, neither did they have criminal records nor had they ever been to prison, with the exception of el Abboubi's short detention in June 2013. By contrast, the Internet played an important role in their radicalisation process, especially for el Abboubi.

All three jihadists made the leap from a "cognitive" form of radicalisation, based on the acquisition of radical attitudes, values and beliefs, to a "behavioural" form, associated with actual participation in a range of radical activities, including illegal and clandestine ones, which can culminate in violent extremism and terrorism (among others, Neumann, 2013).

In relation to "cognitive" radicalisation, all three expressed serious grievances. In particular, as mentioned above, el Abboubi critiqued the alleged vices of the Western style of life (Vidino, 2014, pp. 63-66); Sergio complained about religious discrimination and Islamophobic attitudes in the country (Serafini, 2015b, pp. 42, 46-47); and Delnevo expressed strong disagreements with Italy's foreign policy toward Muslim-majority nations. [21] Some of the grievances are not uncommon in sections of Europe's Muslim communities. 
However, the three Italian radicals framed problems and solutions in the perspective of jihadist ideology, with its principles, narratives, and symbols.

All three did not hesitate to publicly advance their radical ideas, at least to a certain degree. For instance, el Abboubi in September 2012 asked the police if he could obtain the permit necessary to organise a public protest in Brescia, adding that he planned to publicly burn Israeli flags during the event and display banners containing offensive material targeting US President Barak Obama. A demonstration eventually took place in front of a mall on October 6, 2012; reportedly less than a dozen people attended it (Vidino, 2014, p. 60). Delnevo and Sergio subscribed to a public petition in favour of the niqab. Sergio participated in a national TV show and gave various newspaper interviews.

In particular, these three jihadists were active on social media, where they expressed extremist positions, including incitement to hatred (e.g., Alfonso and Persano, 2013; Serafini, 2015b, p. 32). Each of them had at least one Facebook profile; they have since been removed. El Abboubi and Delnevo created their own YouTube channel. El Abboubi used a Twitter account for a short time in 2012.[22] As mentioned earlier, he also started two blogs, Sharia4Italy and Banca Islamica.

These public statements, together with other sources (in particular, testimonies of family members, friends, acquaintances and other relevant actors), make it possible to dig into their lives. However, it is not easy to reconstruct their original motivations. In general, their decision to embrace jihadism and travel to Syria was driven by similar, but not identical reasons. Apparently, el Abboubi became disgusted by the values and institutions of Western society and wanted to rebel against them; Delnevo was fascinated by the mission of fighting for an alleged 'good cause', in solidarity with suffering (Sunni) Muslim populations, and by the idea of sacrificing his life for Islam (in particular, Delnevo, 2014, 2015); while Sergio was obsessed with the idea of purity, based on a fundamentalist and militant interpretation of the religion, [23] and was attracted by the cause of the newly-proclaimed "caliphate".

At some point these three radicals decided to take action and leave for Syria. They moved on to a "behavioural" form of radicalisation in connection with jihadist armed groups. Unfortunately there is little open-source information about the ways in which these Italian citizens travelled to Syria, via Turkey. According to the information currently available, they were not directly recruited by militant organisations through a traditional top-down process of recruitment, but rather actively sought contacts with various facilitators, on the basis of a bottom-up process. Both el Abboubi and Sergio had connections with Albanian jihadists. This fact confirms the influence of Balkan extremists in Italy (Giacalone, 2015). However, other details are still vague, unknown or not publicly available. For example, the role of "IS member" Abu al-Harith still needs to be clarified.

Importantly, with the possible exception of el Abboubi in 2013, there are no indications that these homegrown jihadists were interested in preparing attacks in Italian territory (cf. Hegghammer, 2013).

Another noteworthy aspect concerns the families of the jihadists. All three remained in touch with their family members back home. However, their reactions were significantly different. Delnevo's family was not aware of his decision to leave for jihad. As mentioned earlier, after his departure, his mother travelled to Syria to find him. His father repeatedly asked him to return to Italy on the phone. However, after the tragic death of the young man in June 2013, Carlo Delnevo, a practicing Catholic before his recent conversion to Islam, 


\section{Journal of Terrorism Research}

although not sharing Giuliano / Ibrahim’s extremist ideas, described his son as an idealistic "hero" (Delnevo, 2015).

El Abboubi's family seemingly presented more ambiguous positions. For example, his mother expressed partial reservations; in an intercepted conversation, she told him: "When they conquer Syria and enter Palestine, I'll let you go. It is a war against Israel and you don't fight Arabs” (Bianconi, 2015). Moreover, she reportedly said to a friend: "He went for the honour of jihad" (Giornale di Brescia, 2015). According to prosecuting authorities, el Abboubi's "family never let him lack support and understanding" (Giornale di Brescia, 2015).

On the other hand, all of Sergio's family members converted to a very strict form of Islam, approved of her decision to leave for Syria and, following her constant requests, even agreed to move to the territory under the control of the self-proclaimed "caliphate". Eventually Maria Giulia / Fatima was able to recruit her whole family, using both the carrot and stick approaches. In particular, she did not hesitate to resort to emotional blackmail (Serafini, 2015b, pp. 114ff.).

Seemingly, Delnevo's and el Abboubi's families have, in different ways, painfully tried to balance their original non-militant attitudes and ideas with attachment and consideration for their loved one. They have handled this on their own.

In general, working with families can be an important tool in preventing violent extremism. Thus, it is worth stressing that at present, unlike other countries (cf. Gielen, 2015), Italy does not have actual support initiatives for the parents and relatives of foreign fighters and, more generally, it has not developed fullfledged counter-radicalisation and de-radicalisation programmes (Vidino, 2015b). On the contrary, Italy has given priority to a criminal justice approach, based on the prosecution of foreign fighters. This approach has its advantages and disadvantages (cf. Reed et al., 2015). For example, in some conversations with their parents from Syria, both el Abboubi and Delnevo explicitly mentioned the fear of being arrested and convicted in Italy as a reason not to return home. On the other hand, family members and friends were discouraged from passing on information to authorities.

\section{Conclusions}

This article has explored the current extent of Italy's Sunni jihadists in Syria and Iraq. It has sought to fill a gap that exists in the scientific literature on the Italian case. Clearly, further research is needed on this topic. Furthermore, a comprehensive analysis of this complex phenomenon would require a broad multi-causal approach. In particular, many scholars of terrorism distinguish three levels of analysis: the micro-level concerning individuals, the meso-level concerning groups, networks or organisations and the macro-level concerning the social environment (among others, Crenshaw, 1981). Developments at one level of analysis may impact other levels. This explorative article has focused mainly on the micro level, on the basis of currently available information. Nevertheless, future research should examine the meso- and the macrolevels and analyse the interaction between these three levels.

Overall, the number of foreign fighters connected with Italy appears to be limited, especially when compared to other European countries. In particular, today very few Italian citizens are publicly known to have joined 


\section{Journal of Terrorism Research}

armed groups in Syria or Iraq. However, these individuals deserve attention because they are particularly difficult to detect and stop.

This contribution has examined the stories of three Italian nationals: Giuliano (alias "Ibrahim") Delnevo, a convert who died in combat in the Aleppo area in 2013; Anas el Abboubi (alias "Anas Abu Shaku" or "Anas al-Italy"), a second-generation immigrant of Moroccan descent who joined the ranks of the so-called Islamic State (IS) in Syria in 2013; and Maria Giulia Sergio (alias "Fatima az Zahra"), a convert who is now in the selfproclaimed "caliphate", where she has received firearms training. Delnevo and el Abboubi served as foreign fighters, while Sergio, as a woman, is an aspiring foreign fighter for IS.

These three case studies present interesting similarities but also important differences and they do not permit the identification of a common profile of an Italian foreign fighter. This fact confirms the widely held assumption that the radicalisation process is based on individual pathways that differ from one person to another (among others, Hafez and Mullins, 2015).

In their experience in conflict areas, jihadists such as Delnevo, el Abboubi and Sergio could access militant groups and gain in social status, acquire weapons training and entrench anti-Western positions. As mentioned earlier, el Abboubi was already being investigated on suspicion of planning attacks in Italy, before his departure for Syria.

In conclusion, it is clear that Italian foreign fighters and muhajirin ("emigrants") in Syria and Iraq, though relatively few in number, potentially pose a significant and complex security threat.

About the author: Francesco Marone is a Research Fellow at the University of Pavia and an Adjunct Lecturer at the University Institute Umanitaria-Ciels in Milan (Italy). Moreover, he is currently a Fellow of the Centre for Advanced Studies (CAS) at the University of Rijeka (Croatia). He was a Visiting Fellow at Aberystwyth University (Wales, UK) and a Visiting Postdoctoral Researcher at the Hebrew University of Jerusalem (Israel). His research interests include terrorism and political violence, radicalisation, and migration and security. 


\section{References}

Alfonso, D. and Persano, B. Ucciso in Siria, voleva il Liguristan. 'Già indagato per terrorismo'. La Repubblica, Genoa local edition (June 18, 2013).

Ansa. Renzi, chi uccide in nome dio non è eroe, no indulgenza. Ansa (January 15, 2015).

Assumma, A. 'Vi racconto perché ho scelto l'Islam'. L'Espresso (October 30, 2013).

Bakke, K. M. (2014). Help wanted? The mixed record of foreign fighters in domestic insurgencies. International Security, 38(4), 150-187.

Berizzi, P. In cella dai genitori di Lady Jihad: 'Credere in Allah non è terrorismo'. La Repubblica (July 14, 2015).

Bianconi, G. Le conversazioni via Facebook. 'Reclutati quaranta italiani'. Corriere della Sera (March 26, 2015).

Biloslavo, F. Litaliana che è pronta a colpirci. Il Giornale (January 11, 2015).

Biloslavo, F. Quando 'Lady Jihad' disse in tv: 'Santanchè sparge odio e violenza'. Il Giornale (January 14, 2015).

Biloslavo, F. Lallegra famiglia (italo-albanese) che combatte con il Califfo. Panorama (March 11, 2015).

Biloslavo, F. Dal trucco al velo, vi racconto la svolta del clan femminile guidato da Lady Jihad. Il Giornale (July 3, 2015).

Byman, D. and Shapiro, J. (2014). Be Afraid. Be a Little Afraid: The Threat of Terrorism from Western Foreign Fighters in Syria and Iraq. Policy Paper No. 34. Brookings Institution.

Calandri, M. 'Tre mesi di odissea a un passo dal fronte, volevo salvare mio figlio ma ho fallito'. La Repubblica, Genoa local edition (June 20, 2013).

Cook, D. (2005). Women Fighting in Jihad?. Studies in Conflict and Terrorism, 28(5), 375-384.

Corriere della Sera. La lettera delle sorelle Sergio a Ciampi in difesa del burqa. Corriere della Sera, Milan local edition (January 13, 2015).

Crenshaw, M. (1981). The causes of terrorism. Comparative Politics, 13(4), 379-399.

Dellacasa, E. Il diario di 'Ibrahim', jihadista genovese: capi in hotel, noi in tenda. Corriere della Sera (August 24, 2014).

Delnevo, C. Vi racconto Giuliano [I'll tell you about Giuliano], YouTube video. September 2, 2014. Available at: https://www.youtube.com/watch?v=8B8NLaHS4HA.

Delnevo, C. (2015). Il figlio musulmano. Tricase: Youcanprint.

Giacalone, G. (2015). La rete jihadista albanese e le ripercussioni italiane. Analysis No. 288. ISPI (July 2015).

Gielen, A.-J. (2015). Supporting Families of Foreign Fighters. A Realistic Approach for Measuring the Effectiveness. Journal for Deradicalization, 2, 21-48.

Giornale di Brescia. Anas, da Vobarno alla Siria 'per l'onore della Jihad'. Giornale di Brescia (March 25, 2015).

Gonzales, P. Vera Jourova: 'Près de 6000 Européens sont partis faire le djihad'. Le Figaro (April 12, 2015).

Grasso, M. Indagato l'amico del genovese ucciso in Siria. Il Secolo XIX (August 29, 2014).

Grasso, M. La madre del genovese morto in Siria: 'Io una minaccia? Loro ci usano'. Il Secolo XIX (February $28,2015)$. 


\section{Journal of Terrorism Research}

Grasso, M. and Indicre. M. Il genovese 'Umar' e la morte di Delnevo: 'È inutile, tanto voi non capite’. Il Secolo XIX (August 28, 2014).

Hafez, F. (2014). Shifting borders: Islamophobia as common ground for building pan-European right-wing unity. Patterns of Prejudice, 48(5), 479-499.

Hafez, M., and Mullins, C. (2015). The Radicalization Puzzle: A Theoretical Synthesis of Empirical Approaches to Homegrown Extremism. Studies in Conflict and Terrorism, 38(11), 958-975.

Hegghammer, T. 2013. Should I Stay or Should I Go? Explaining Variation in Western Jihadists' Choice between Domestic and Foreign Fighting. American Political Science Review, 107(1), 1-15.

Heinke, D. H. and Raudszus, J. (2015). “German Foreign Fighters in Syria and Iraq”. CTC Sentinel, 8(1), 1821.

Il Sole 24 Ore. Pinotti: nelle file dell'Isis 87 foreign fighters passati dall'Italia. Il Sole 24 Ore (September 20, 2015).

Imarisio, M. 'L'italiano ucciso in Siria reclutava altri guerriglieri. Corriere della Sera (June 20, 2013).

Italian Interior Ministry. “Alfano: 'Stato di massima allerta contro il terrorismo”'. Press release, Rome, January 19, 2015. Available at http://www.interno.gov.it/it/notizie/alfano-stato-allerta-massimo-contro-terrorismo.

Italian State Police. “Operazione Sceen Shot”. Press release, Brescia, June 20, 2013. Available at: http:// questure.poliziadistato.it/Brescia/articolo-6-91-56067-1.htm.

Italian State Police. "Milan: 5 arrested on suspicion of international terrorism”. Press release, Milan, July 1, 2015. Available at: http://www.poliziadistato.it/articolo/view/39239/ (English version).

Klausen, J. (2015). Tweeting the Jihad: Social media networks of Western foreign fighters in Syria and Iraq. Studies in Conflict and Terrorism, 38(1), 1-22.

La Repubblica. Jihad, il padre del ragazzo ucciso: 'Ragazzi non partite'. La Repubblica, Genoa local edition (August 28, 2014).

Lahoud, N. (2014). The Neglected Sex: The Jihadis' Exclusion of Women from Jihad. Terrorism and Political Violence, 26(5), 780-802.

Marone, F. (2015). Il nuovo volto del terrorismo jihadista. Il Mulino, 64(2), 293-302.

Micalessin, G. La guerra santa di Al Italy il ‘bresciano’. Il Giornale (June 21, 2014).

Moore, C. (2015). Foreign Bodies: Transnational Activism, the Insurgency in the North Caucasus and “Beyond". Terrorism and Political Violence, 27(3), 395-415.

Neumann, P. R. (2013). The trouble with radicalization. International Affairs, 89(4), 873-893.

Neumann, P. R. "Foreign fighter total in Syria/Iraq now exceeds 20,000; surpasses Afghanistan conflict in the 1980s". International Centre for the Study of Radicalisation and Political Violence (ICSR), January 26, 2015. Available at: http://icsr.info/2015/01/foreign-fighter-total-syriairaq-now-exceeds-20000-surpassesafghanistan-conflict-1980s/.

Pantucci, R. (2014). The British Foreign Fighter Contingent in Syria. CTC Sentinel, 7(5), 17-21.

Perešin, A. (2015). Fatal Attraction: Western Muslimas and ISIS. Perspectives on Terrorism, 9(3), 21-38.

Perešin, A. and Cervone, A. (2015). The Western Muhajirat of ISIS. Studies in Conflict and Terrorism, 38(7), 495-509. 


\section{Journal of Terrorism Research}

Persano, B. Il padre di Giuliano Delnevo: 'Mio figlio è morto da eroe per salvare un amico'. La Repubblica (June 19, 2013).

Petenzi, W. Nel mirino dello studente pure questore e piazza Loggia. Corriere della Sera (June 13, 2013).

Petenzi, W. Isis, reclutatori nei paesi Balcani. La pista bresciana porta in Albania. Corriere della Sera (March 5, 2015).

Piccardo, G. Giuliano Ibrahim Delnevo: l'amico Umberto Marcozzi: 'Mi scrisse che in Siria i martiri profumano.... L'Huffington Post (June 18, 2013).

Pieracci, A. Dal Marocco alla Cecenia. Lorizzonte del male di Ibrahim. La Stampa (June 19, 2013).

Plebani, A. (Ed.). (2015). New (And Old) Patterns of Jihadism: Al-Qa'ida, the Islamic State and Beyond. Milan: ISPI.

Preve, M. Trovato il diario del genovese ucciso in Siria per la Jihad. La Repubblica, Genoa local edition (August 23, 2014).

Reed A., de Roy van Zuijdewijn, J. and Bakker, E. (2015). Pathways of Foreign Fighters: Policy Options and Their (Un)Intended Consequences. ICCT Policy Brief. The International Centre for Counter-Terrorism - The Hague (ICCT).

Rich, B. and Conduit, D. (2015). The Impact of Jihadist Foreign Fighters on Indigenous Secular-Nationalist Causes: Contrasting Chechnya and Syria. Studies in Conflict and Terrorism, 38(2), 113-131.

Rodella, M. Il 'terrorista' di Vobarno torna a casa. Corriere della Sera (June 29, 2013).

Rodella, M. L'islamista di Vobarno sparito nell'inferno siriano. Corriere della Sera (November 9, 2013).

Rodella, M. Il rapper che canta la Jihad ora è scomparso nel nulla. Corriere della Sera (August 23, 2014).

Rodella, M. Anas, due tentativi per arrivare in Siria. L'ultima telefonata: siamo sotto attacco. Corriere della Sera (March 26, 2015).

Rodella, M. Reclutavano combattenti dell'Isis. Tre jihadisti finiscono in manette. Corriere della Sera, (March 26, 2015).

Rodella, M. La madre di Anas: 'Siete qui per dirmi che è morto'. Corriere della Sera (March 27, 2015).

Rodella, M. Jihad, era 'pronto ad arruolarsi': resterà sotto sorveglianza per 5 anni. Corriere della Sera (April $25,2015)$.

Santucci, G. Così il colonnello del Califfo reclutava i combattenti in Italia. Corriere della Sera (July 2, 2015).

Sarfatti, M. Maria Giulia Sergio, alias Fatima: 'Grazie al Corano ho capito cosa vuol dire sentirsi una donna'. Incontro con lady Jihad. L'Huffington Post (January 13, 2015).

Sergio, M. G. Terrorismo, le intercettazioni della jihadista italiana. YouTube video, July 3, 2015. Available at https://www.youtube.com/watch?v=dQuber1xcZo (in Italian). (This YouTube video presents the original audio of some intercepted conversations between Sergio and her Italian family, while she was in Syria Serafini, M. Italian Woman Jihadist Speaks, Corriere della Sera (English version) (July 7, 2015).

Serafini, M. (2015b). Maria Giulia che divenne Fatima. Storia della donna che ha lasciato l'Italia per l'Isis. Milan: Corriere della Sera.

Sistema di Informazione per la Sicurezza della Repubblica. Relazione sulla politica dell'informazione per la sicurezza 2014 [2014 Report on Security Intelligence Policy] (February 13, 2015). 


\section{Journal of Terrorism Research}

Tempera, N. Ė caccia alla bolognese ideologa dell'Isis. Il Resto del Carlino (July 2, 2015).

Valle Sabbia News. 'La pacifica convivenza non è in discussione'. Valle Sabbia News (June 13, 2013).

Vergani, M. (2014). Neojihadist Prosumers and Al Qaeda Single Narrative: The Case Study of Giuliano Delnevo. Studies in Conflict and Terrorism, 37(7), 604-617.

Vidino, L. (2014). Home-Grown Jihadism in Italy: Birth, Development and Radicalization Dynamics. Foreword by Stefano Dambruoso. Milan: ISPI and European Foundation for Democracy.

Vidino, L. (Ed.). (2015a). L'Italia e il terrorismo in casa. Che fare?. Milan: ISPI.

Vidino, L. (2015b). Sharia4: From Confrontational Activism to Militancy. Perspectives on Terrorism, 9(2), $2-16$.

Whine, M. (2007). Common Motifs on Jihadi and Far Right Websites. In B. Ganor, K. Von Knop and C. Duarte (Eds). Hypermedia Seduction for Terrorist Recruiting. Amsterdam: IOS Press, 76-95.

\section{Notes}

[1] For example, according to Hegghammer's original data for the period 1990-2010, about one in nine foreign fighters returned for an attack in the West. On the other hand, those who were involved in plots were twice as likely to kill (Hegghammer, 2013).

[2] References to Italian foreign fighters and jihadists in Syria and Iraq can be found in Vidino (2014) and Vergani (2014) and also in Plebani (2015) and Vidino (2015a).

[3] According to media reports, Andrea Lazzaro started to frequent the local headquarters of Forza Nuova ("New Force"), an ultra-Catholic neo-fascist party, around 2003, when he was a teenager, and later got close to Fronte Nazionale ("National Front"), another small, more secular, far-right party (Imarisio, 2013; Grasso and Indicre, 2014). According to a Genoese comrade, Lazzaro "read a lot" and was "interested in religions"; however, "his permanent idea was anti-Americanism". In fact, at the time Lazzaro started a radical blog called Lantiamericanista ("The Anti-Americanist"), now no longer available. Apparently he has been particularly attracted to a quest for spirituality. Around 2007, Andrea / Umar explained his recent conversion to Islam with these words: "in my last year of high school I had the urge to look for an alternative. Something that was beyond ephemeral trends, that helped me understand the meaning of life [...] I wanted to look for a connection with the transcendent, that went beyond material reality, beyond the produce-consume-die cycle" (Grasso and Indicre, 2014).

This transition from right-wing extremism to Islamism may seem odd, especially considering that today Islamophobic discourses have become a feature of many divergent parties and movements in the far-right camp (among others, Hafez, 2014). However, these two radical ideologies also have some general themes and motives in common (cf. Whine, 2007), including ultra-conservatism, aversion to pluralism and liberalism, anti-globalisation outlooks, anti-Semitism, anti-Americanism, contempt for a materialistic view of reality. The last two elements - anti-Americanism and contempt for materialism - appear to be crucial in Lazzaro's pathway.

[4] See: https://www.youtube.com/user/liguristanTV. Delnevo uploaded nine low-quality videos.

[5] In March 2013, this brigade merged with two other jihadist groups and became Jaish al-Muhajirin walAnsar (Army of Emigrants and Helpers) (cf. Moore, 2015). 


\section{Journal of Terrorism Research}

[6] Eva Guerriero visited the area alone, without the support of the government (Preve, 2014). To the contrary, at the beginning of 2015, after the Italian intelligence system referred in general terms to the potential threat posed by "family members / friends (including women)" of foreign fighters in the annual report to Parliament (Sistema di Informazione per la Sicurezza della Repubblica, 2015, p. 31), Guerriero, pressured by the media, bitterly said in a newspaper interview: “They [Italian authorities] used us [Delnevo's family], intercepted us, tailed us. And that didn't even help save my son's life. I wonder if this is still a constitutional State" (Grasso, 2015). Italian authorities have made no comment.

[7] MTV Italia, Nel ritmo di Allah [In the Rhythm of Allah], 2012; a trailer of this report is available at https:// www.youtube.com/watch?v=EObUCoujN0o\&feature=youtu.be. The mini-documentary on el Abboubi ( $\mathrm{La}$ storia di McKhalifh, "The Story of McKhalifh") is no longer available online (see Vidino, 2014, pp. 61-62).

[8] See: https://www.youtube.com/user/MCKHALIF. El Abboubi uploaded four videos.

[9] See his blog: http://banca-islamica.blogspot.it/. El Abboubi wrote only one post, on August 18, 2012.

[10] Sharia4 is a transnational movement with autonomous branches in various European countries. It is well-known for its provocative rhetoric and deliberately confrontational protests. In some cases, local branches, especially Sharia4Belgium, also facilitated the passage of jihadists to Iraq and Syria (Vidino, 2015b).

[11] El Abboubi started a dedicated blog: http://sharia4italy.blogspot.it/. There are only two posts, both written on May 19, 2012.

[12] The two Albanian citizens, Alban Haki Elezi, 38, and Idris Elvis Elezi, 20, also tried to recruit an Italianborn teenager of Tunisian descent who lived in Como, not far from Milan. In the end, the boy backed out (Bianconi, 2015; Rodella, 2015d).

[13] Fatimah, known as az Zahra ("the Shining One" in Arabic), was the youngest daughter of the Prophet Muhammad and Khadijah and the wife of Ali.

[14] The text of the petition is quoted in Corriere della Sera (2015) (in Italian).

[15] Aldo Kobuzi was born in northwestern Albania in 1991; he worked as a mechanic. His younger sister Serjola had already left for Syria in 2013 together with her husband, Mariglen Dervishllari, and their child, Hataab. Kobuzi's brother-in-law died of leukemia in Syria (Biloslavo, 2015c).

[16] As is well-known, the Hijra is the migration of the Prophet Muhammad and his Companions from hostile Mecca to Yathrib (Medina) in 622 CE.

[17] For example, in some 2015 intercepted conversations, Sergio told her family that in Syria she had already used a handgun and a kalashnikov. Furthermore, she said: "I make du'a [supplication in Islam] everyday that Abu Bakr al Baghdadi confirms jihad for women (...) because I can't wait to die as a shahid" (Serafini, 2015b, pp. 132-133).

[18] Marianna Sergio divorced in February 2015 and returned home to live with her parents.

[19] Specifically, Sergio's father and mother were charged only with the crime of "transfers" for the purposes of international terrorism. This type of crime was introduced by an antiterrorism law passed in April 2015 (Law 17 April 2015, no. 43). By contrast, Maria Giulia's sister was also charged with the crime of "association" for the purposes of international terrorism (Serafini, 2015b, pp. 145-146).

[20] Haik, a Canadian national of Syrian descent, allegedly is a IS supporter and had an important role in indoctrinating Maria Giulia / Fatima, her sister Marianna and other women via the Internet (Serafini, 2015b, 


\section{Journal of Terrorism Research}

pp. 59-63). She was born in Bologna, Italy, in 1985 and lived in the country for many years, before she moved to Riyadh, in Saudi Arabia (Tempera, 2015; Serafini, 2015b, p. 59).

[21] In a video uploaded on his YouTube channel on April 29, 2012, Delnevo addressed "the President of the Italian Republic Mario Monti and his government" (actually, Monti was President of the Council of Ministers, that is head of government, not head of state) and asked the unconditional withdrawal of Italian army from Afghanistan, particularly in a period of economic crisis (https://www.youtube.com/ watch? $\mathrm{v}=$ wdM9x8oN778). In another video uploaded on October 3, 2012, he denounced the "invasion of Somalia" by the Kuffar (unbelievers) (https://www.youtube.com/watch?v=0NH mhOlBY4). However, it is worth stressing that the Syrian civil war does not involve a non-Muslim invader.

[22] See: https://twitter.com/anas_abdu. Cf. Klausen (2015).

[23] Tellingly, before she left for Syria, Sergio told an acquaintance: "I was Catholic but I embraced Islam because it is a cleaner religion" (emphasis added) (Biloslavo, 2015d). 